\title{
THE POST-COLONIAL IDENTITY OF DURBAN
}

\author{
ADRIAN KOOPMAN \\ Zulu Studies, School of Arts, University of KwaZulu-Natal
}

\section{A B S T R ACT}

Many scholars have pointed out that when changes in political regimes take place, these are frequently accompanied by politically-inspired changes of place names. In this article, I look at the naming of the South African east coast city Durban, starting with the name Durban itself, and the various suggestions that have been mooted for its replacement. In particular, I look at the Zulu name for Durban (eThekwini - 'the place of the bay') and its suitability as a new name for the city.

The article then goes 'inside' the city and looks at the recent re-naming of a considerable number of Durban's streets, and the public reaction to this. Both the re-naming and the public reaction are placed within the context of re-naming globally.

\section{[1] INTRODUCTION}

Maoz Azaryahu, in a seminal article about the politics of renaming streets, says that the French Revolution "set an example for the use of streets and squares for the purpose of political representation" (Azaryahu 1996, 313). According to Azaryahu, in 1792 the statue of Louis XV, erected in 1763 in the square named Place Louis XV, was demolished. In its place a "colossal" figure of Liberty was erected, and the square renamed Place de la Revolution. Today the same square is named Place de la Concorde.

In a later article, Azaryahu sees the renaming of this square in 1792 as starting a trend:

The French revolution set a model, and renaming streets has since become a common feature of major changes in political regime and ruptures in political history. Renaming streets has become a conventional 'ritual of revolution', in David Kertzer's suggestive phrase. (Azaryahu 1997, 481)

In the example of Paris above, the name Place de la Concorde is apparently the third name for that particular square. In other cities, names may change even more frequently. (Azaryahu 1996) says of street name changes in the city of Berlin that 
The transition from a monarchy to republic, the rise of Hitler to power, the surrender of Nazi Germany, national division, and reunification were all manifest in corresponding renaming of streets (Azaryahu 1996, 318).

While Azaryahu (1996), Azaryahu (1997), Yeoh (1992), Light (2004) and Alderman (2000) have concentrated on the renaming of streets specifically, place names of all sorts may undergo change as a result of political regime change. Catherine Nash is talking of place names generally when she says that "[o]ver the last two centuries, government bodies have systematically named and renamed places in Ireland" (Nash 1999, 457). McCarthy (2002) gives a specific example of the renaming of a coastal town in County Cork in Ireland, known as the Cove of Cork until 1849 when it was renamed Queenstown in honour of a visit by Queen Victoria. In 1921 the name of the town reverted to Cove, "with the Irish spelling Cobh." (p. 37)

Horsman (2006) gives examples of the renaming of mountains and peaks in the Pamirs, "a mountain range and high plateau area in the Tien Shan, Karakoram and Hindu Kush mountain complex" (op.cit., 281). He shows (op.cit., 282) that these mountains have gone through five distinct historical periods: the 'traditional' period (pre-Tsarist), the Tsarist period, the Soviet Period of 1917 to 1953, the Soviet Period of 1953 to 1991, and finally the Post-Soviet Period. Horsman says of the name changes that have taken place that

Political regimes have often sought to represent and manipulate landscapes in order to promote their own ideological and political objectives. This has been carried out in order to affirm their legitimacy, control of their territory and promote their ideological norms. (Horsman 2006, 279)

South Africa has undergone two political regime changes in the $20^{\text {th }}$ century. In retrospect the regime change of 1948 can be considered as a minor change, as one minority government, led by the United Party and its mainly Englishspeaking white supporters, was replaced by another minority government: the National Party with its mainly Afrikaans-speaking white supporters. A limited amount of renaming of places took place at that time. A good example is that of the main thoroughfare in the city of Bloemfontein, which changed from St.George's Street, a name redolent with English symbolism, to Voortrekkerstraat, a name just as powerfully symbolic of Afrikaans nationalism ${ }^{1}$ (Lubbe 2003). The name of Hendrik Verwoerd, prime minister of South Africa from 1958 to 1966, and widely

[1] The voortrekkers were the various groups of Dutch-speaking farmers who 'trekked' (migrated) with their ox-wagons, away from the English-dominated Western Cape, to find new homes in the hinterland of present-day South Africa. 
known as the 'architect of apartheid', became the new name of several major roads, towns, dams, and so on during this period, for example the Hendrik Verwoerd Dam on the Orange River, the H.F. Verwoerd Airport in Port Elizabeth, and the town of Verwoerdburg adjacent to Pretoria. (http://en.wikipedia.org/ wiki/Hendrik_Verwoerd, accessed 6.1.2011)

The major regime change in South Africa took place in 1994, when the white minority government of the National Party was replaced with the black majority party the African National Congress (ANC), with Nelson Mandela president of the 'new South Africa'. The Union of South Africa, which came into being on $31^{\text {st }}$ May 1910, was a dominion of the British Empire. On the $31^{\text {st }}$ May 1961, the Union of South Africa became The Republic of South Africa, so it could be argued that it was in 1961 that South Africa lost its 'colonial' status. However, as the country continued under white minority rule right through to 1994, to most South Africans the country remained a bastion of colonialism until the election which saw the ANC take over the government. The term 'post-colonial' in my title, then, refers to Durban and other cities in South Africa since 1994.

The toponymic changes that have taken place in South Africa post-1994 have been extensive, and are well detailed and exemplified in Jenkins et al. (1996) and Jenkins (2007). Verwoerd's name was one of the first to go: the Hendrik Verwoerd Dam became the Gariep Dam, using the Khoisan name for the Orange River ${ }^{2}$, the H.F. Verwoerd Airport became the Mathew Goniwe Airport ${ }^{3}$, and Verwoerdburg became Centurion. Later, Voortrekkerstraat, which as we saw above had replaced St. George's Street as the name of the main thoroughfare in Bloemfontein, became Nelson Mandela Drive ${ }^{4}$. In fact Nelson Mandela's name soon became as ubiquitous a toponym as MacQuarie is in New South Wales, Australia (see Miles 2010 and Bryson 2000, 92-93).

\section{[2] DURBAN AND ITS ONOMASTIC BACKGROUND}

Durban is a major coastal city on the eastern coast of South Africa. One of the busiest ports in the southern hemisphere, it is a popular tourist venue, because of its year-round warm climate and extensive beaches. The earliest known name for the bay on which Durban is situated is the 1450 name given by Portuguese seafarers - Rio de Natal - and names for the Bay of Natal in French, Dutch, English, Italian and Portuguese are found on many early maps predating the first settlement by white explorers, traders and missionaries. Survivors from early shipwrecks left short-lived names in Dutch, English and other languages for the bay and other topographical features, but it was only from 1820 onwards when Europeans started to settle that more permanent names were given. The early name Port Natal,

[2] Although the Orange River has simply remained the Orange River.

[3] Named "after a local hero of the resistance who had been murdered by police" (Jenkins 2007, 119).

[4] Nelson Mandela is the 'ikon' referred to in Johan Lubbe's title. 
which referred to the bay as well as the young growing township, was officially replaced by D'Urban after the name of the then Governor of the Cape, and within a few years this had become Durban, still today the official name of the city, and the name found in gazetteers and atlases world-wide. The Zulu name eThekwini was also early recognized, and many other Zulu names have been used for Durban or significant parts of Durban over the years. Some of these, like kwaMalinde, isiBubulungu, iFenya and eGagasini I have discussed in other articles ${ }^{5}$. Official names like Port Natal and Durban, used on document and title deeds, have always lived side by side with unofficial names like Durbs and eMdubane. The current municipal newsletter is named eGagasini Metro, a reference to Durban's status as one of South Africa's few large metropolitan municipalities, as well as the current Zulu nickname for Durban - eGagasini ('the place of the wave' ${ }^{\text {) }}$ )

\section{[3] CHANGING THE NAME OF THE CITY}

Despite the considerable amount of renaming of places which has taken place in South Africa since 1994, very little renaming of towns and cities has taken place. There was a brief flurry of such renaming in the Northern Province in 2002, when the names of ten towns were changed ${ }^{7}$. Largest of these was Pietersburg, which became Polokwane. Others include Ellisras (now Lephalale), Naboomspruit (now Mookgophoong), Potgietersrus (now Mokopane) and Nylstroom (now Modimolle).

In the early 1990s rumours ran rife through South Africa that most of South Africa's major towns and cities would be getting new names, exchanging the current official name to the shadowy unofficial name in Zulu or Sotho or Venda or whatever. Headlines took the form of "Bloemfontein to become Mangaung". It took quite some time before threatened whites realized that Bloemfontein could hardly be getting a 'new' name in the form of Mangaung ('place of the cheetahs'), when local people had been calling Bloemfontein 'Mangaung' since the foundation of the town. EThekwini would not be a new name for Durban; it was in fact an older name than Durban for the same place, and had been used by considerably more people over the years than the name 'Durban'.

Nonetheless, for nearly a decade, there were fears that 'Colonial' names of cities would disappear. What in fact happened was a perfect compromise. In 1999 South Africa was divided into municipalities (the third tier of government below national government and provincial government). Towns, cities and rural areas

\footnotetext{
[5] See Koopman $(2004,2007,2009)$

[6] This nickname for Durban was popularised by K.E. Masinga, the first black announcer for what was then Radio Bantu in the 1960s. He used to refer to himself on the radio as UKE Masinga ogibel' igagasi ('KE Masinga who is riding a wave'), a pun on radio waves and the famous surfing waves of Durban (Koopman 2004, 86). Old Fort Road in Durban, where the local recording studios of the South African Broadcasting Corporation are situated, has been renamed K.E. Masinga Avenue.

[7] (Jenkins 2007, 154).
} 
became Local Municipalities, and, these all combined to form District Municipalities. By Act of Parliament, all these municipalities had to be named. Almost invariably towns and cities with 'colonial' names used their African language vernacular names as the name of the municipality, while retaining the original name for the place. So in South Africa today, the City of Durban is run by the eThekwini Municipality, the City of Pretoria is run by the Tshwane Municipality, and Bloemfontein by the Mangaung Municipality. In Pietermaritzburg, the city council decided not to use the Zulu name eMgungundlovu ${ }^{8}$, but chose the name of the river running through the city, becoming the uMsunduzi Municipality.

The newsletter of the eThekwini Municipality - eGagasini Metro - provides numerous examples of the subtle distinction in function and use in the dualname partnership between Durban and eThekwini. In any issue we find statements like: "eThekwini has recently purchased eight new street sweeping lorries, so the streets of Durban will be cleaner than ever" or "The citizens of Durban have welcomed the idea of paying rates in advance, so eThekwini's finances have never looked better". The municipal newsletter of the uMsunduzi Municipality makes similar distinctions between the names uMsunduzi and Pietermaritzburg. I do not have access to the municipal newsletters of any other cities in South Africa, but in Pietermaritzburg and Durban this onomastic partnership involving place and management works very well indeed.

The Pretoria/Tshwane partnership, however, has been under threat for a number of years. In 2005, the $150^{\text {th }}$ anniversary of the founding of Pretoria, the ANCgoverned City of Tshwane Metropolitan Council decided to change the name of the city from Pretoria to Tshwane (Jenkins 2007, 158). This decision, however, has been difficult to effect. Jenkins (op.cit 158-163, and Jenkins (2010)) gives extensive details of administrative procedures not correctly followed, of court applications instituted against the changes, of ministerial decisions countermanded by later ministers, and so on. By January 2011, the proposed change had still not yet officially taken place. The South African Broadcasting Corporation, however, has been referring to Pretoria as Tshwane for a number of years now, despite court interdictions requiring it to stop this practice.

Of interest in the Pretoria/Tshwane debate has been the number of conflicting theories put forward to explain the meaning and origin of the name 'Tshwane'. of these various theories, the Tshwane Municipality has opted for the one that claims that the area, which is dominated by speakers of the language Pedi, was once ruled by a Pedi chief named Tshwane. Despite there being no records of

[8] There are problems of identity with this name. The founding fathers of Pietermaritzburg apparently decided the Zulu name for the city should be uMgungundlovu, the name of the chief settlement of Zulu king Dingane, whom they had just decisively defeated and whose uMgungundlovu palace they had just burnt to the ground. This transfer of names has never sat well with the local Zulu population, who tend to refer to Pietermaritzburg as eThawini ('Town'), and insist that uMgungundlovu refers to the historical site of King Dingane's main establishment, some $250 \mathrm{~km}$ distance to the north. 
this chief in any written or oral archive, they have 'discovered' his genealogy, and have even apparently 'discovered' an old photograph of chief Tshwane. This photograph has been used to create a bronze statue, and this statue has now been erected in one of the public squares in Pretoria. The late Professor Louis Louwrens, who published an article about the various theories ${ }^{9}$, commented about the Tshwane Municipality's decision ${ }^{10}$ : "It is seldom that one is privileged to be present at the very birth of a legend."

Clearly what we have here is a 'constructed identity', and at the same time, a 'false identity'. Charles Pfukwa, in a recent doctoral thesis on Zimbabwe's Noms de Guerre ${ }^{11}$, which deals with the self-given nicknames, or war-names, of Zimbabwe's guerilla fighters during the 1970s war for independence, talks of "intended identities" as against "perceived identities". The "City of Tshwane" clearly intends its identity to be 'the city of the original chief named Tshwane'. Whether this will become the perceived identity of its residents in the future remains to be seen. I suspect that this 'constructed identity' will very soon find its way into school texts and be permanently embedded as the true identity of the city. After all, one cannot argue with the existence of a bronze statue.

Another 'colonial' city which came under a renaming threat, in 2007, was the Eastern Cape city Grahamstown. A South African Press Association report dated $4^{\text {th }}$ October 2007 reported Grahamstown mayor Phumelelo Kate as saying "Whether it costs the Makana municipality two cents or R100-million to change the name of Grahamstown and the names of other places and landmarks, the names will change". He added that "Grahamstown must go. It's a name we can't be proud of, considering history and given the baggage that it carries," and said that a process to "eliminate the name from the books of this country" was unfolding. He stressed that "only names that make us have nightmares will be changed". Fellow city councillor Theo Fulani said it was 'disturbing' that people were using the issue of costs as a threat to transformation., and stated that "no amount of money could be put on the lives of the many freedom fighters that had been lost during the struggle against apartheid ... if it takes money to transform our country, let it be. We can't stop, we won't stop."

Despite the nightmarish character of the name 'Grahamstown', the political baggage it carries, and the determination of the Makana Municipality councillors to "change the name at all costs", at the beginning of 2011 Grahamstown remains 'Grahamstown'.

The name 'Durban' came under fire in 2003. Jenkins $(2007,104)$ quotes then president of South Africa Thabo Mbeki as saying:

[9] Louwrens (2006).

[10] Personal communication September 2006

[11] Submitted, examined, and accepted in 2007. 
I am embarrassed by the temerity with which the subject of namechanging is approached. There are probably only a handful of places in South Africa named after a white person who wasn't a land-grabbing murderer. The fact that Grahamstown, Harrismith and, say, Durban, are still named after John Graham, Harry Smith and Benjamin d'Urban is appalling.

Four years later 'Zulu history expert' Professor Jabulani Maphalala was quoted in the Sunday Tribune of $26^{\text {th }}$ August 2007 as saying about the name 'Durban':

How can it stay when it is named after a colonial oppressor, Sir Benjamin D'Urban? It is not a secret that he was the governor of the Cape and Natal colonies during the frontier wars. He was complicit in the beheading of chief Hintsa of the Gcaleka tribe, whose head was taken to England.

Maphalala's opinion appears in an article by Sunday Tribune journalist Agiza Hlongwane, headed "eThekwini change a load of bull". The article was a reaction to comments made the previous week by the mayor of Durban Councillor Obed Mlaba, who had apparently said that he felt embarrassed when people asked him about the meaning of Durban's Zulu name 'eThekwini':

A lot of people overseas have asked, 'What does eThekwini mean? Then you start saying 'Well, you see, um, please pass me the milk for my tea', because you are not proud to unpack what it means.

Mlaba's supposed embarrassment, and the phrase "load of bull" in Hlongwane's title, both refer to one of the potential meanings of 'eThekwini'. While the commonly believed explanation is that eThekwini is the locative form of the Zulu noun itheku ('bay, lagoon') giving the city a Zulu name meaning 'place of the bay', it is just as possible that the name is derived from the other meaning of itheku ('animal or man with single testicle'). In my 2009 article where I argue the merits of the two possibilities, I conclude that the original Zulu name for Durban was most likely based on the 'testicular geography' of Durban, namely that from the Berea hills above the city, the round shape of the bay, together with the phallic shape of the promontory ${ }^{12}$ which separates the bay from the Indian Ocean, give the impression of a penis and a single testicle. These two conflicting interpretations have been hotly debated, on and off, in the press and elsewhere, for many years $^{13}$

[12] Called The Bluff in English and iSibubulungu in Zulu.

[13] For details of the lengthy debate in the press from November 1978 to January 1979 see Koopman (2004, $76-79)$. 
While the sub-editors of newspapers may enjoy making suggestive headlines that refer to the single testicle identity of Durban ${ }^{14}$, the question remains "Does Durban need to be renamed?"

In 1998, through an Act of Parliament, the South African Geographical Names Council (SAGNC) ${ }^{15}$ was formed. Among other duties, the SAGNC has gazetted a number of guidelines to ensure some kind of order in changing place names at national, provincial and municipal levels. These include guidelines which state when a place name should be changed, for example when it is deemed offensive, or if it duplicates another existing place name.

The guidelines suggest that a change might be 'appropriate' if evidence is strong that a colonial name replaced an earlier name in an indigenous language, and a number of place-names in South Africa have been changed during the past dozen or so years for this reason. There is no guideline which says that a colonial name should be changed simply in order to expedite and support an overall programme of "Africanising" (i.e. "De-Colonialising") South Africa, although to many critics (usually whites), this often seems to be that case. Nor is there any guideline that says that if a name carries "colonial baggage", it should be changed.

In the case of Durban, which has marketed itself internationally for many years as a premium tourist venue under this name. the costs of changing to a name like eThekwini, which has no international resonance, would be high indeed. But supposing sufficient pressure is put on the relevant authorities to rename Durban, what would be the likely new name?

The original Zulu name eThekwini would obviously be a prime candidate. But the city tourist authorities would have to be extremely careful about how they market the city under this name. "Come to The Place of the Bay" has attractive possibilities; the same cannot be said of "Come to The Place of the Single Testicle". On the other hand, Mpumelelo Mbatha, former chairman of the KwaZulu-Natal Provincial Geographical Names Committee, was quoted in Hlongwane's 2007 Sunday Tribune article as saying that "tourists would very excited to know about this" and in the same article former Cape Town Tourist CEO Sheryl Ozinsky said that the city should be capitalising on the 'single-testicle' story:

It's actually hilarious. I can't see what's embarrassing about it. Tourists love stories and its always nice to have a story to tell ... What's wrong with a bull with one testicle?

The Zulu name eThekwini is not, however, the sole candidate to replace the name Durban. Hlongwane tells us, at the end of his article, that

[14] In addition to the headline "eThekwini change a load of bull" in the Sunday Tribune of 26.4.2007, the Pietermaritzburg-based newspaper The Witness of 24.4.2007 offered the headline "Durban's name is a bit of a balls-up, says red-faced mayor".

[15] For specific details of this, see Jenkins2005:v 
KwaKhangel' amankengane is the name King Shaka gave to what is now Durban. KwaKhangela, in short has been mooted as a replacement for Durban.

The statement "KwaKhangel' amankengane is the name King Shaka gave to what is now Durban" needs a little elucidation. Bryant $(1929,644)$ tells us that when King Shaka sent the umGumanqa regiment to the vicinity of Port Natal in the 1820 s to keep an eye on the newly arrived white settlers, they became known by the nickname uKhangela-amankengane ('keep an eye on the vagabonds'). Over the years it has been generally accepted by a variety of writers and authorities that this regiment established a barracks on the shore of the bay, named KwaKhangela, and it is this name that has morphed into the current name Congella, the name of an area of wharves, repair docks, and shipping-related establishments on the western side of the bay. Unfortunately, there is no evidence whatsoever, in either written or oral sources of the existence of this supposed barracks named 'KwaKhangela'. What is very well documented is the existence of the small village erected by Boer commandant Andries Pretorius in the 1840s on the site of the modern Congella. Pretorius named this small settlement 'Congella', almost certainly adapting the name of the second-largest establishment of King Dingane ${ }^{16}$ - KwaKhangela - situated on the White Mfolozi River several hundred kilometres north of Durban. Such a transfer of name would have followed the pattern set by Pretorius' fellow Boers who had transferred the name uMgungundlovu (Dingane's principal establishment) to their new town Pietermaritzburg a few years previously ${ }^{17}$. It would be ironic indeed if the name 'Durban' should be discarded on the grounds that it is carrying offensive colonial baggage, to replace it with a name only associated geographically with Durban because a Boer commandant 'borrowed' a Zulu name from several hundred of kilometres away.

Durban still has to make a decision about changing the name of the city. As I see it they could

- retain the current name Durban, which ex-President Thabo Mbeki sees as commemorating a "land-grabbing murderer" and which many other, mainly black, citizens see as "carrying colonial baggage"; or

- change it to eThekwini, with its image of a mono-testicular bovine, which will at least allow wags to make jokes about Durban being 'on the ball' or a place where 'tourists can really have a ball'; or

- change it to KwaKhangela, the name Shaka supposedly gave to Durban, which will have the benefit of linking the city onomastically to its new air-

[16] Shaka's half-brother and successor to the Zulu throne.

[17] See footnote 8 above. 
port $^{18}$, but will require careful hushing up of the links to Boer Commandant Andries Pretorius and his bayside village Congella.

\section{[4] STREET NAME CHANGES IN DURBAN}

So far, we have looked at the name of the city as a whole, within the context of already executed changes, as well as threatened city and town name changes in other parts of South Africa. We now need to go 'within' the city and look at recent changes to Durban's street names. Azaryahu has pointed out that

Politically motivated renaming of streets is a common feature of periods of revolutionary changes. As a ritual of revolution, the 'renaming of the past' is a demonstrative act of substantial symbolic value and political resonance, introducing the political ideological shift into ostensibly mundane and even intimate levels of human activities and settings. (Azaryahu 1997, 479)

Yeoh makes the same point about the symbolic value when she says that

... naming a place, whether as a deliberate act or informally, is also a social activity; it embodies some of the struggle for control over the means of symbolic production in the urban landscape ... (Yeoh 1992, 313)

Duncan Light is one of a number of scholars who make the point that street names may have dual functions. Their primary function is (as with almost any kind of name), a referential one. They designate entities. In a city, this designative function is, in Light's word, to "serve the purpose of orientation within the built environment" (Light 2004, 154). But as Light also points out (ibid.), street names may have other, more symbolic functions:

Those names which commemorate key events or personalities from a country's history are a manifestation of political order, and can be significant expressions of national identity with a powerful symbolic importance. They represent a particular view of the national past which is directly mapped onto urban geography.

Azaryahu makes the dual function of street names equally clearly:

"Alphanumerical street names, as the case of New York so convincingly demonstrates, completely fulfill the primarily practical function of street names, that is to distinguish between different streets,

[18] The King Shaka International Airport, situated $40 \mathrm{~km}$ north of Durban, was opened in 2010 just in time for visitors to the FIFA Soccer World Cup in June of that year. 
to provide the users of the city with spatial orientation, and to regulate administrative control over the city. The symbolic function of a street name as a vehicle for commemoration is subordinate to the practical function." (Azaryahu 1996, 312)

Note that both Light and Azaryahu talk of 'commemorative names', names which commemorate 'key events or personalities from a country's history'. While South Africa has (to the best of my knowledge) not gone for names such as $25 \mathrm{de}$ Septembro, 24 de Julho, Organizaçao da Naçoes Unidas, Praça 21 de Outubro, Praçada Indepencia, Resistencia and Guerra Popular ${ }^{19}$, new names replacing older names of streets in South African towns have almost invariably commemorated an individual. When the City Council of Durban renamed 181 streets in 1980, all the new names commemorated individuals seen as important in South Africa's recent history. There is no space here to give more than three examples of the new names, and for each a short phrase indicating the historical importance of the person commemorated in the new name, the old street name, and the significance of the old name.

new name: Steve Bantu Biko Road

historical importance: Steve Biko was a major ANC martyr

old name: Mansfield Road

significance: named after the early Mansfield family resident in the area

new name: Gen. Joseph Nduli Street

historical importance: activist, ANC organiser, MK commander

old name: Russell Street

significance: named after Lord John Russell, Prime Minister of Great Britain in 1846

new name: Chris Hani Road

historical importance: assassinated former president of the SACP

old name: North Coast Road

significance: descriptive name

[19] All taken from an undated map of Maputo, Mozambique, published by Map Studio. Maputo (or the Mozambican government) are also apparently keen on naming streets after other countries, and we find street names such as Angola, Tanzania, and Zimbabwe. Another, which combines event and toponym is Acordos de Lusaka. 
An analysis of the new street names for Durban shows that they most belong to a single group: heroes, stalwarts and martyrs of the 'liberation struggle', the ANC-led and dominated powers struggle against colonialism, white domination and apartheid ${ }^{20}$ :

'long-time President of the ANC Women's League',

'giant of the liberation struggle',

'veteran ANC politician and recruiter',

'long-time struggle hero',

'SACP struggle activist'.

'MK member killed in action',

'early struggle stalwart and ANC politician',

'former ANC Youth League President',

'ANC trade unionist and Robben Island ${ }^{21}$ veteran', and

'young lion of the SACP'

Both Azaryahu $(1996,317)$ and Light $(2004,156)$ point out that politically motivated renaming involves a two-fold process: decommemoration and commemoration. Light puts it like this:

"Renaming streets involves simultaneous processes of de-commemoration and a new commemoration. The new names may reflect a radically different narrative of national history, and may be a component of a broader process of redefining senses of national identity. Thus, replacing one set of street names with another set entails inscribing discourses and counter-discourses of power and identity onto topography."

To see whether or not the many new names of Durban's streets "reflect a radically different narrative of national history", we need to look at the names which have been replaced. Several of the older names were descriptive in nature: North Coast Road, Broad Street, Commercial Road, Brickfield Rd (where originally a brick factory existed) Essenwood Road (lined with 'essenwood' or 'ironwood' trees), old Fort

[20] ANC: African National Congress; MK: uMkhonto Wesizwe ('Spear of the Nation' - the armed wing of the ANC); SACP: South African Communist Party.

[21] The infamous prison for political prisoners of the apartheid government, on Robben Island a few kilometres offshore from Cape Town. It is now a popular tourist venue. 
Road. These names can be considered politically neutral, with no 'colonial' profiles, apart from the last-named, perhaps, which refers to the fort built by British forces in the 1840s to protect themselves against attacks from Boer Commandant Andries Pretorius' forces. But most of the replaced names were themselves commemorative, and can be roughly divided into three groups: commemorating (1) long-time residents of the locality on which a road was newly laid out, (2) individuals who contributed in one way or another to the good of the city, and (3) colonial officials, for the most part not resident in the city (or even in the country). Examples of older, now replaced, street names from the three groups are:

Long-term residents: McDonald Road (an original resident of the area); Moore Road (long-time early inhabitant of the area); Marriott Road (long-standing family resident in the locality); Warwick Avenue (old resident family)

Contributing individuals: Field Street (William Swan Field, first Collector of Customs and Resident Magistrate in the 1850s), Francois Road (Dr Charles A Francois, Town Councillor and later Deputy Mayor, 1914 to 1924), Brickhill $R d$ (James Brickhill, leading trader and businessman in the 1850s)

Colonial officials: Grey Street (Earl Grey, British Secretary of State for the Colonies in the 1850s), Russell Street (Lord John Russell, Prime Minister of Britain in the 1850s), West Street (Martin West, first Lieutenant-Governor of Natal 1845 to 1849 )

Although not commemorating persons, old street names like Blair Atholl Road (named for a small town in Perthshire, Scotland) and Stamford Hill Road (named for a suburb of London) are undoubtedly 'colonial' in nature.

Few though these examples above are, there can be little doubt that the historical identity of the urban landscape of Durban has undergone considerable change.

A cursory analysis of the streets taken as a whole shows that the Durban City Council was not targeting specific names for replacement. Although a more intensive mapping analysis needs to be done, it seems fairly clear that what they were targeting was major thoroughfares and socially-economically significant roads, and these often were named for individuals. Their approach contrasts strongly with the deliberations of the City Council in KwaZulu-Natal capital Pietermaritzburg, who decided much earlier in the 2000s to rename selected roads and streets in the city, with the publicly stated intention of "redefining senses of national identity" (to use Light's words again). They specifically did NOT target streets already carrying a commemorative name, and only changed the names of streets carrying a neutral name like Berg ('mountain') Street, Commercial Road, and Longmarket Street. The Pietermaritzburg City Council were also careful not to choose only the names of people strongly linked with one political party, or even 
with 'the struggle', but chose a wide range of people, all of whom had contributed specifically to the well-being of Pietermaritzburg in one way or another. The people whose names now grace the urban landscape of Pietermaritzburg were writers, theologians, community leaders, philanthropists and - yes - some of them were ANC-linked activists who had contributed to the struggle. They also only changed the names of 16 streets, a comparatively small number when looking at the situation in Durban.

This conciliatory approach did not, however, prevent a great public outcry, mainly conducted through the "Letters to the Editor" columns in the local newspaper The Witness ${ }^{22}$. Considerable as the public outcry against street renaming was in Pietermaritzburg, it was nothing compared to the level of protest which took place in Durban, to which we now turn.

[5] RESISTANCE AGAINST THE RENAMING OF STREETS IN DURBAN

Light (2004) has pointed out that

[S]treet names - like other public memorialisations of a nation - are subject to multiple readings and interpretations. As such, they may become the focus of struggle and resistance over the significance of the past which they commemorate (p. 156).

Azaryahu provides more detail on the issues of 'legitimacy', 'political dissent and opposition', and 'resistance to renaming':

The intentions of political elites and the extent of popular support for these notwithstanding, the challenge to the legitimacy of names as well as the historical traditions they represent is embedded into the politics of street names. The belonging of commemorative street names to the symbolic foundations of the established order makes them, together with other symbolic expressions of power, potential focal points of political dissent and opposition, whereas the rejection of names by a population, or segments of it is a profound act of resistance. In a case where street names are perceived as being associated with political repression, the resistance may take various forms. One possibility is to avoid altogether the use of the official name in an act that amounts to civil disobedience. (Azaryahu 1996, 315)

An excellent example of the 'challenge to the legitimacy of names' and 'acts that amount to civil disobedience' is provided by Alderman (2000). When African

[22] This form of protest lasted for more than a year, and has been well documented in Hilterman \& Koopman (2003). 
Americans living in Chattanooga in Tennessee requested the city council to change the name Ninth Street to M.L.King, Jr, Boulevard, and the council refused

... 300 African Americans marched along the street. Armed with ladders and singing "We Shall Overcome", they defiantly yet temporally renamed the street by pasting street signs with bumper stickers that read “Dr. ML King, Jr. Blvd.” (Alderman 2000, 673).

The points made by both Light and Azaryahu above, if applied to the case of Durban, would seem to apply to two different instances of opposition and resistance. Street names commemorating the daughters of Queen Victoria, colonial officials, whites-only early residents, and English and Scottish towns would unquestionably appear to post-apartheid South Africans (especially of the ruling party) as being "symbolic foundations of the established order" and "symbolic expressions of power [that are] potential focal points of political dissent and opposition". Given such an interpretation it is not surprising that a new politically order (the ANC-led Durban City Council) would want to 'challenge the legitimacy of [earlier] names as well as the historical traditions they represent'.

The resistance which I now wish to detail, though, i.e. opposition to the new names, is more that of "the rejection of names by a population, or segments of it". The two segments of population who have protested about the new names are (1) white residents of the city who identify with the colonial heritage of the city and/or support the political opposition party the Democratic Alliance (DA), and (2) mainly black Zulu-speaking supporters of Mangosuthu Buthelezi's Inkatha Freedom Party (IFP), another opposition party.

Resistance to the new names has taken many forms, including

- court challenges to the legitimacy of the street renaming, brought by DA members of the city council,

- mass protest meetings and marches, sometimes violent, mainly by IFP members,

- extensive and ongoing letters of protest to the local press, mainly (but not entirely) by white residents ${ }^{23}$, and

- the spray-painting and other physical desecration of new name signboards, mainly by white residents of streets so affected.

Much of the protest has been directed personally against Dr Michael Sutcliffe, the Durban City manager, whom many people see as personally responsible for

[23] Identified by Professor Colin Gardner, ANC-supporting Council Speaker of Pietermaritzburg during the renaming protests there as "the great letter-writing public". 
the "destruction of our heritage", to quote a phrase which has appeared again and again in protest letters.

The resistance against the new names has been documented in an article by Turner (2009) who quotes viewpoints both for and against the renaming of Durban's streets. Mayor Obed Mlaba (whom we met earlier in this article requesting more milk in his tea when asked what 'eThekwini' meant), as the leader of the ANC-dominated Durban City Council, was of course obliged to support the changes, and his message to Durban residents in the municipal newsletter Ezasegagasini, quoted by Turner reads:

The spoils of democracy include ensuring that the towns and cities, the roads and streets reflect the people and history, the collective culture of ALL South Africans. Universal franchise alone will not undo decades of oppression and racism (Turner 2009, 129).

On the other hand, "political commentator Darryl Illbury had strong words to say" to say about a "power-hungry cabal led by Mayor Obed Mlaba and City Manager Mike Sutcliffe". Turner quotes him:

Through collusive dealing and double-dealing, and their cunning influence over a insipidly malleable city council, these two have abused the trust of a largely ignorant and uninvolved electorate to entrench themselves in a position where they influence the lives of hundreds of thousand of people at a whim. They pull the strings and you have to dance. Like it or not they now have the power to change the names of roads and places at will; and this is what they are doing. A number of the name changes even salute those whose extremist vitriol demanded imposition of a Soviet-style one-party autocracy on this country rather than a multi-party democracy. (Turner 2009, 128)

Strong words indeed, but Illbury was not alone in expressing his anger. Similar emotions could frequently be found in the letter columns of various Durban based newspapers . The following is just a brief selection. From The Independent on Saturday dated 14.03.2009 we read

The mayor of Durban tells us ... to respect our history and not obliterate it.

No, Mr Mayor, it is you who are obliterating history not us - whether or like it or not our early forefathers of Durban did some good and have created history. 
A writer to The Tribune of 26.07.2009 offered the following opinion:

Gone, too, are the old familiar street names replaced by long, difficult unpronounceable ${ }^{24}$ names of the heroes of the liberation movement.

Not a street name has been left untouched. All the names of people who built the city are gone, trampled by the jackboots of the ANC and its bully Mike Sutcliffe.

And in similar vein from The Independent on Saturday of 14.03.2009:

Then there are the great ego-boosting activities such as wholesale street naming, which apart from being divisive, serves only to cause frustration and confusion among visitors and locals. Honouring heroes of the past is very necessary but surely this should be done in a manner which does not lead to wholesale confusion.

These letters are fairly representative of a groundswell of anger and frustration among a certain segment of the population. Changes of whatever sort often produce anger, frustration and resistance, but nowhere else in South Africa have there been mass protest marches, spray-painted street signs and such vitriolic letters to the press. We need to ask why there has been such a negative reaction. Turner, whose phrase 'odonymic warfare' in the title of her 2009 article is a fair reflection of the reaction of (mainly white) residents of Durban, identities three reasons:

(i) They felt that there had been insufficient consultation and that the ANC majority in the City Council had simply 'steamrollered' the changes;

(ii) They felt that the history and heritage of the city, reflecting the numerous individuals who had contributed to the development and growth of the city, had been obliterated; and

(iii) They felt that the new names were completely one-sided, as they only reflected ANC 'heroes'.

Let us look briefly at each of these in turn:

(i) insufficient consultation: this has been the subject of legal approaches by DAsupporting city councillors, and in 2010 the court ruled that the council had acted legally and given the citizens of Durban sufficient time to react. My personal interpretation, based on extensive press reports, is that the City

[24] The names referred to are, of course, easily pronounceable to the majority of the citizens of KwaZuluNatal, who are Zulu mother-tongue speakers. 
Council gave the citizens of Durban comparatively little time (a month or two), certainly when compared to the Pietermaritzburg City Council, which gave its citizens three years to react to proposed changes.

(ii) obliteration of history and heritage: This is partially true. While statement like the one recorded above, namely that "not a street name has been left untouched. All the names of people who built the city are gone" are wild exaggerations, given that several hundred of Durban's street names still reflect the names of earlier, white citizens. But, as indicated earlier, the name Brickfield Road reminds urban citizens of a brickfield esatblished earlier in the vicinity, and the name Old Fort Road is a reminder of an important historical clash between British and Boer Forces in the formative days of the city. These reminders are no longer part of the visual fabric of the city.

What is of specific interest in the issue of 'obliteration of history and heritage' is that it was the ANC-majority government which in Act No.25 of 1999 set up a national heritage body, the South African Heritage Resources Agency (SAHRA). Its aim, reflected on its 2008 poster, is as follows:

\begin{abstract}
The South African Heritage Resources Agency (SAHRA) has a mandate in terms of the National Heritage Resources Act No.25, 1999, to manage heritage resources for the present and future generations. According to the Act it is the policy of SAHRA to conserve and manage heritage resources (both sites and objects) associated with oral tradition or living heritage.
\end{abstract}

The poster goes on to detail various aspects of 'Living Heritage', including 'Cultural Tradition, Oral History, Performance and Rituals', and includes both 'Popular Memory' and 'Street names' in its list of that which is required to be preserved in terms of Act 25 of 1999. The poster of the following year, 2009, shows prominently a number of street signs, suggesting that the preservation of street names is a priority. Two things intrigue me personally about the 1999 Act vis-a-vis Durban's street name changes. One is that none of the legal challenges to the renaming appear to have thought of using this act as part of the legal action. The other is that I am yet to see any statement about street renaming from the director of SAHRA, who incidentally lives in and has his office in Durban. One might perhaps have thought that a government agency which claims street name preservation as one of its important goals could at least have said something when 181 street names are replaced. 
(iii) only ANC 'heroes': again, this is only partially true. The first name in an alphabetical list of the new names is that of famous author Alan Paton ${ }^{25}$, a founder member of the Liberal Party. Other names are given with no indication of whether those commemorated in new street names were members of the ANC or not. But there is certainly no question that the list leans very heavily towards supporters of the ANC and related bodies such as the South African Communist Party, the military wing of the ANC uMkhonto Wesizwe, the South African Indian Congress, and the like.

It seems useful, perhaps, in looking at the reasons for such resistance to street renaming in Durban to look at a wider, global context, and here Azaryahu makes some very relevant and pertinent remarks about street names in general, and about the reaction of citizens when their familiar street names are changed. First we need to look at the point he makes about new regimes needing to assert themselves in overt acts of authority:

The renaming of streets is a conventional manifestation of a stage of liminal transition in political history, when the need of the new regime for legitimacy and self-presentation is especially high. In a revolutionary context the renaming of streets, in addition to the more spectacular pulling down of monuments, is an act of political propaganda with immense proclamative value and public resonance (Azaryahu 1996, 318).

That the renaming of streets has "public resonance" is unquestionably true of the case of Durban. It is also clear from the tone of many letters to the press in Durban over the last two or three years that many citizens see street renaming as "political propaganda". Azaryahu continues:

Through renamings, the new regime proclaims the beginning of a new era while demonstrating both its resoluteness and its self-confidence. The act of renaming asserts that a radical restructuring of power relations in society has indeed been accomplished, or is underway, and it indicates a profound reconstruction of social and political institutions. As is often the case in such circumstances, renaming streets is both a celebration of triumph and a mechanism for settling scores with the vanquished regime.

The last sentence here seems particularly relevant to the Durban scenario. Without once again quoting from contributions to "Letters to the Editor" pages

[25] Honoured in Pietermaritzburg by changing the name of the main highway from Durban leading into the city from Durban Road to Alan Paton Avenue. There was not one word of protest about this change. 
in the press, I can confidently assert that many of the white minority in Durban today feel that the 'new' government is both 'celebrating a triumph' and 'settling scores with the vanquished regime'.

Another issue raised by Azaryahu relates to the primary function of street names, namely to serve as spatial orientation guides in the urban environment. Street names are of course not the only orientation guides used by long-term residents of a city: all sorts of other aspects of the urban landscape serve as visual guides too, such as certain buildings, facades, street furniture, monuments and statues, open spaces, parks and gardens, and many more. These visual aids, together with street names, accumulate in the memory of long-term residents, and enable them to find their way about complex cities. Such visual aids are not available to short-term residents such as visitors and tourists, and tourists are frequently and reliably identified by their habit of consulting a map and then peering up at the nearest street sign. Azaryahu (1996) acknowledges this when he says "For a tourist, of course, renamings mean spatial confusion, especially before a stage of equilibrium is reached and the city maps are again trustworthy as 'true' representations of the city." (p. 317)

Yet another aspect of street renaming is that street names accumulate individual layers of memories. To most members of an urban environment, Victoria Street, say, is known to be the most convenient street to use when you want to go from the railway station to the city market (the orientation function). But to one person the name Victoria Street may evoke the memory of "Why, that's the street with the wonderful little café on the corner where I met my future wife". To another person the same name may mean "That's the street the tram followed when we used to take it to go to the seaside". To me personally the Durban street name Musgrave Road evokes memories of wonderful swooping curves on the ups and downs of that road. Wonderful, that is, for a young boy riding his bicycle across the Durban Berea hills on the way to school. This accumulation of "place-specific memories' is also acknowledged by Azaryahu as something that can easily be lost when names change:

Renaming a street has a substantial effect not only on the city but also on its human experience and cognition. A rude intervention in routinized practices and traditional relations between ordinary people and their habitat effects a cognitive dissonance and mental and communication disarray, at least temporarily. Renamings also disrupt the continuous accumulation of place-specific memories that are meaningful beyond generational differences and constitute a substantial element of the urban cultural texture. (Azaryahu 1996, 317) 
The anger expressed in so much of the protest that has taken place in Durban over the last few years about street renaming may well be a result of 'cognitive dissonance' and 'temporary communication disarray'.

Another factor about street names is that they are "another way of institutionalising a particular narrative of national history into the everyday consciousness of the urban populace" (Light 2004, 154). Street names are always visible. They are always there when one travels around the urban environment, on each corner and intersection. They are needed when an envelope or parcel is addressed. Newspaper and television advertisements exhort us to buy at such-and-such an establishment on such-and-such a street. This 'everyday consciousness' is used, suggests Azaryahu (1996), by astute politicians to put their message across in a subtle manner:

[T] he utilization of street names for commemorative purposes enables an official version of history to be incorporated into spheres of social life which seem to be totally detached from political contexts or communal obligations, and to be integrated into intimate realms of human interactions and activities.

Commemorative street names provide a distinguished example of the intersection of hegemonic ideological structures with the spatial practices of everyday life. (Azaryahu 1996, 321)

\section{[6] THE 'INSENSITIVITy FACTOR}

To return to the Durban case study, one last factor that could account for high anger and resistance levels, could be termed the 'insensitivity factor', and here we are referring to specific and individual cases involving specific names. I mention just four of them; Turner (2009) gives specific details of all of these and a number of others.

\section{[6.1] Edwin Swales VC Drive changed to Solomon Mahlangu Avenue:}

Edwin Swales, a Durban-born pilot of the South African Air Force in World War II, was posthumously awarded the Victoria Cross in 1945 for 'gallant conduct' in flying his crippled aircraft back to friendly territory in such a way that he himself was killed but all members of the crew were able to parachute to safety ${ }^{26}$. Solomon Mahlangu left South Africa aged 19 in 1976 to undergo specialist military training in Angola, returned a year later with two companions, and was involved in a shooting incident with police which left two dead. He was hanged two years later in Pretoria on a charge of the murder of two white civilians ${ }^{27}$. To supporters of the armed struggle against apartheid, Mahlangu's killing (or involvement in

[26] (McIntyre 1956, 46).

[27] http://www.durban.gov.za/durban/government/renaming/bios/. 
the killing) of two white policemen is a heroic act, and he is considered a notable ANC martyr. To another segment of the population, particularly those identifying with the 'gallant conduct' of Edwin Swales, the name of their hero has been replaced with the name of a murderer, and many have expressed their feelings about this publicly.

\section{[6.2] Kingsway to Andrew Zondo Drive:}

Kingsway was the name of a major thoroughfare in the coastal resort town Amanzimtoti, which although it lies some $20 \mathrm{~km}$ south of the city of Durban, falls within the ambit of the wider Durban municipality. In September 1986 19-year-old Andrew Zondo was sentenced to death for planting a bomb in a rubbish bin in an Amanzimtoti shopping centre on Kingsway, which resulted in numerous severe injuries and five deaths including that of three children (Turner 2009, 124). As a result of the recent street name changes, the erstwhile Kingsway is now Andrew Zondo Road. Again, one sector of the population may well regard Zondo as a 'struggle hero' and 'liberation martyr'. To still-living relatives of those killed or maimed in the bomb blast, however, this renaming may appear not only insensitive but distinctly provocative.

\section{[6.3] Mangosuthu Highway to Griffiths Mxenge Highway}

This proposed change reflects a different kind of power dynamic in the province of KwaZulu-Natal to those mentioned above: here the issue is not one of different world-views of 'colonial-minded whites' versus 'liberation-struggle blacks', but rather that of different mainly black-supported political groups. Mangosuthu Buthelezi is the long-term president of the KwaZulu-Natal based opposition political party the Inkatha Freedom Party (IFP), the hereditary chief of the powerful Buthelezi clan, and the son of Princess Magogo Zulu, daughter of Zulu king Dinizulu (1868-1913). In other words he is a man of considerable status who enjoys considerable support in his home province. It was the threat to change the name Mangosuthu Highway to Griffiths Mxenge Highway (honouring, not surprisingly, an 'ANC stalwart and struggle hero') that brought thousands of angry IFP on a protest march to the city hall. To the best of my knowledge, this is the only proposed name change which was not carried out in the end, and Mangosuthu Highway remains Mangosuthu Highway.

\section{[6.4] Point Road to Mahatma Gandhi Road}

Point Road for many years was the name of a road circling the Durban harbour on its northern edge, and the name is associated in the minds of most Durban residents with sleazy dives and strip clubs, with drugs, alcohol abuse and prostitution. Many Durban residents were dismayed, therefore, when it was proposed to name this road in commemoration of Mahatma Gandhi. They felt that the philosophies 
espoused by Gandhi were the very antithesis to the activities characteristic of Point Road. (Turner 2009, 124). On the other hand, there were those who believed that the name of Mahatma Gandhi might well have a benign influence on the nature of Point Road, and strangely enough, this does seem to be what has happened. A Sunday Tribune report of 13.09.2009, under the heading "Red light district fades away", stated inter alia that

It ... seems prostitutes have taken their wares from Mahatma Gandhi (formerly Point Road) and opted for quieter residential suburbs, leaving the Point area.

When the Sunday Tribune visited the area last week the streets were empty and clean.

A drive along the infamous prostitute hang-out at night revealed the same situation.

I myself had occasion to visit the Point area of the harbour late in 2010, and drive along the newly-renamed Mahatma Gandhi Road, and certainly the road and the area generally bore no resemblance to the sleazy dock-side suburb of my youth.

The point of this last story, as with the three others above, is that it is usually only one sector of the population which sees certain street names changes as insensitive. Others might well see the same change in a much more positive light.

\section{[7] CONCLUSIONS:}

The proposed and actual changes to the identity of Durban have caused much heated debate. While the debate around the possible changes to the name Durban itself have been somewhat muted, the debate about street name changes has been considerable. This is almost certainly to do with the fact, mentioned above, that the street names have daily impact on the lives of urban residents.

Within the global context, the street name changing in Durban seems 'normal' and inevitable. Writer after writer sees such changes as predictable when there is a change of political regime. As for the heated nature of the debate, Meiring gets right to the point when she writes:

The inherent qualities of names make them instruments of heated debates. No name is completely neutral in the collective memory of a society and its various networks, because the very essence of names is their descriptive backing, the things people and society identify with when using the name. (Meiring 1994, 75)

Given then, that the street reaming in Durban can be seen as inevitable, the only curiosity, to my mind, is why the ANC-dominated Durban City Council waited 
for some thirteen or so years after taking power in 1994 to make these changes. I have quoted Azaryahu above as saying that "Through renamings, the new regime proclaims the beginning of a new era while demonstrating both its resoluteness and its self-confidence". One can hardly claim that 2007 is still part of a new era for a political regime voted into power in 1994.

The other lesson to be learnt from global examples of renaming places is that each cycle of renaming is no more than that - part of a continual cycle of change. Azaryahu's examples of the changes of street names in Berlin, and Horsman's examples of the changing of the names of mountains and peaks in the Pamir range over different and succeeding political hegemonies, should make it clear that the new names that have given Durban's urban landscape a new identity are not necessarily permanent. As Light (2004) puts it:

[S]treet names are not eternal. A change in political order is frequently accompanied by the redefining of the national past through the renaming of streets [and] new narratives of national history and identity are inscribed onto the urban landscape (p. 154).

Azaryahu (1996) makes a similar point:

In their capacity both as historical references and as spatial designations they provide for the conflation of history and geography. Potentially contested and eventually challenged, commemorative street names concretize hegemonic structures of power and authority. (p. 312)

The ephemeral nature of urban identity is not always recognised by those currently in power. For example, ANC politicians have on a number of occasions boasted that "the ANC will be in power until the second coming of Christ". Some might remember a similar boast made by Nazi leaders in the 1930s. Shirer reminds that Hitler boasted in 1933 that the Third Reich "would endure for a thousand years" (as cited in Shirer 1964, 18). Later he makes the pithy remark that "After twelve years, four months and eight days... the Thousand-Year Reich had come to an end." (p. 1353)

It may well be that in less than a generation from that the recent uproar about changing names of streets and other places in Durban will be no more than a footnote in historical textbooks (if mentioned at all), and even newer urban identities will have been forged. 


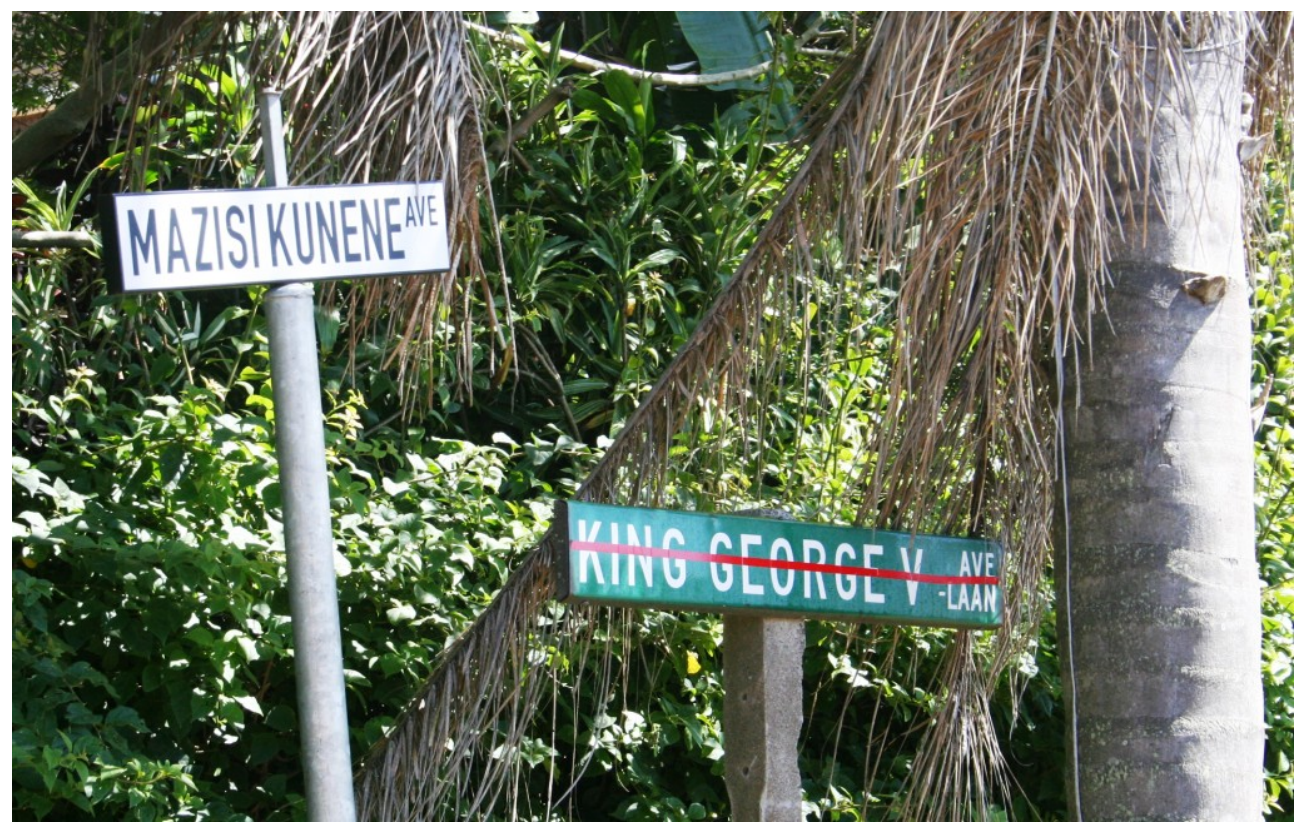

FIGURE 1: King George V is replaced by Mazisi Kunene, 'struggle' poet who returned from exile to become "The Poet Laureate of Africa"

\section{REFERENCES}

Alderman, D.H. 2000. A Street Fit for a King: Naming Places and Commemoration in the American South. The Professional Geographer 52(4). 672-683.

Azaryahu, M. 1996. The power of commemorative street names. Environment and PlanningD: Society and Space 14. 311-330.

Azaryahu, M. 1997. German reunification and the politics of street renaming: the case of East Berlin. Political Geography 16(6). 479-493.

Bryant, A.T. 1929. Olden Times in Zululand and Natal. London: Longmans.

Bryson, B. 2000. Down Under. London: Transworld Publishers.

Hilterman, T. \& A. Koopman. 2003. “A High Degree of Wayward Folly" - an analysis of public response to a proposal to rename streets in central Pietermaritzburg. Nomina Africana 17(2). 1-36.

Horsman, S. 2006. The politics of toponyms in the Pamir mountains. Area 38.3. 279-291.

Jenkins, E. 2007. Falling into Place. Claremont: David Philip. 
Jenkins, E. 2010. Tshwane and the Law. Nomina Africana 24(1). 41-75.

Jenkins, E.R., P.E. Raper \& L.A. Möller. 1996. Changing Place Names. Durban: Indicator Press.

Koopman, A. 2004. The Names and the naming of Durban. Natalia 34. 70-87.

Koopman, A. 2007. The Names and the naming of Durban. Onoma 42. 73-88.

Koopman, A. 2009. A re-look at the semantics of 'eThekwini' or why Durban's mayor needs more milk in his tea. Nomina Africana 23(2). 33-60.

Light, D. 2004. Street names in Bucharest, 1990-1997: exploring the modern historical geographies of post-socialist change. Journal of Historical Geography 30. 154-172.

Louwrens, L. 2006. Die oorsprong en betekenis van die pleknaam "Tshwane". SuidAfrikaanse Tydskrif vir Eietydse Geskiedenis 20(1). 33-39.

Lubbe, J. 2003. Van heilige tot ikon: die geskiedenis van die naamgewing van een van Bloemfontein se strate. Nomina Africana 17(1). 5-20.

McCarthy, P. 2002. The Road to McCarthy. London: Hodder and Stoughton.

McIntyre, J. 1956. Origin of Durban Street Names. Durban: W.E. Robertson, Ltd.

Meiring, B. 1994. Toponymic Innovation and Social Change. Nomina Africana 8(1). 65-79.

Miles, J. 2010. MacQuarie names our places. Placenames Australia: Newsletter of the Australian National Place Names Survey September 2010.

Nash, C. 1999. Irish placenames: postcolonial locations. Transactions of the Institute of British Geographers 24(4). 457-480.

Shirer, W. 1964. The Rise and Fall of the Third Reich. London: Pan Books.

Turner, N. 2009. Odonymic warfare: The process of renaming streets in Durban, South Africa. Nomina Africana 23(1). 113-133.

Yeoh, B. 1992. Street names in colonial Singapore. The Geographical Review 82.3. 313-322. 
AUTHOR CONTACT INFORMATION

Adrian Koopman

Zulu Studies, School of Arts, University of KwaZulu-Natal

Private Bag X01

3209 Scottsville, KwaZulu-Natal

SOUTH AFRICA

koopman@ukzn.ac.za 